\title{
Kaja Zapędowska-Kling
}

Uniwersytet Łódzki, Wydział Studiów Międzynarodowych i Politologicznych

e-mail: kaja.kling@gmail.com

\section{INTERSEKCJONALNOŚĆ W POLITYCE SPOLECZNEJ}

\section{INTERSECTIONALITY IN SOCIAL POLICY}

DOI: $10.15611 /$ sie.2017.2.02

JEL Classification: J16, I14, B54, H53

Streszczenie: Głównym celem artykułu jest wykazanie zasadności zastosowania analizy intersekcjonalnej w badaniach nad polityką społeczną. Intersekcjonalność jest interdyscyplinarną perspektywą badawczą wywodzącą się ze studiów nad postkolonializmem i nierównościa$\mathrm{mi}$ (minority studies). Obecnie analiza intersekcjonalna ma szerokie zastosowanie w naukach społecznych oraz w badaniach nad kulturą. Główna teza referatu bazuje na przekonaniu o tym, że krzyżujące się, interferujące ze sobą kategorie społeczne (takie jak płeć, wiek, klasa, rasa i etniczność, (nie)pełnosprawność, poziom wykształcenia oraz inne) tworzą zróżnicowane ryzyka socjalne. Autorka wskazuje na przykłady dyskryminacji wielokrotnej oraz dokonuje przeglądu różnych instrumentów polityki społecznej, które w sposób konstruktywny adresują kwestie społecznych nierówności. Publikacja stanowi analizę korzyści wynikających $\mathrm{z}$ adaptacji perspektywy intersekcjonalnej na etapie planowania i tworzenia polityk społecznych.

Słowa kluczowe: intersekcjonalność, polityka społeczna, ryzyko socjalne, nierówności społeczne, dyskryminacja wielokrotna.

Summary: This article aims at proving the validity of intersectional analysis in research on social policy. Intersectionality is a new interdisciplinary approach rooted in postcolonial and minority studies. Today intersectional approach is more and more commonly applied in social sciences and cultural studies. The article's main thought emphasizes the fact that intersecting and interfering social categories (such as gender, age, class, race and ethnicity, (dis)ability, education, and others) result in diversified social risks. The author points at the examples of multiple discrimination and reviews different social policy tools, which address the issue of social inequality in a constructive way. The publication offers an analysis of potential benefits resulting from applying intersectional approach in the process of social policy planning and policy-making.

Keywords: intersectionality, social policy, social risk, social inequalities, multiple discrimination. 


\section{Wstęp}

Individuals' economic, political, cultural, subjective, and experiential lives intersect to create a whole that is more than the sum of its parts

[Ekonomiczne, polityczne, kulturowe, subiektywne i empiryczne wymiary życia jednostek krzyżują się, aby stworzyć całość, która jest czymś więcej niż sumą części składowych - tłum. aut.] $]^{1}$

Punktem wyjścia rozważań zawartych w niniejszym artykule jest przekonanie, że nadrzędnymi celami polityki społecznej są sprawiedliwość społeczna i bezpieczeństwo socjalne. Głównym celem zaadaptowania paradygmatu intersekcjonalności w polityce społecznej jest inkluzja społeczna tych grup społecznych, które były dotychczas ignorowane lub wykluczane ${ }^{2}$, czyli - pośrednio - zwiększenie sprawiedliwości społecznej i bezpieczeństwa socjalnego i jednoczesne zapobieganie wystąpieniu wybranych ryzyk socjalnych. Według wykładni Trybunału Sprawiedliwości „pojęcie sprawiedliwości społecznej zależy od istniejącego w danym społeczeństwie systemu norm i wartości, jest zatem uwarunkowane zarówno historycznie, jak i klasowo. Pojęcie sprawiedliwości jako zasadniczo nadrzędne służy do oceny zasadności społecznych zróżnicowań. Jeżeli w podziale dóbr i w związanym z tym podziale ludzi występują niesprawiedliwe różnice, wówczas różnice te uważane są za nierówności”’3. Sprawiedliwość społeczna, jakkolwiek wieloznacznym jest pojęciem, wiąże się ściśle z pojęciem nierówności społecznych. W pojęcie sprawiedliwości społecznej wpisana jest nie tyle równość rozumiana jako równość statusu społecznego, co równość dostępu, równość możliwości rozwoju, równość szans. Jak podkreśla Sierpowska, ,sprawiedliwość społeczna nie oznacza [...] rozdzielania dóbr jednakową miarą ani zapewnienia wszystkim dobrobytu czy też jednakowej pozycji ekonomicznej. Chodzi raczej o stworzenie możliwości, których wykorzystanie prowadzi do poprawy warunków bytowych (dostęp do edukacji, opieki medycznej, zapewnienie mieszkania)"4. Cele te realizuje polityka społeczna, której głównym podmiotem jest państwo. „Państwo jest głównym dystrybutorem dóbr [...] i ono kształtuje poczucie sprawiedliwości lub niesprawiedliwości społecznej”s. Jednocześnie, co podkreśla perspektywa intersekcjonalna, zinstytucjonalizowana polityka społeczna utrwala - nieintencjonalnie - niektóre wymiary nierówności społecznych. Instytucje reprodukują mechanizmy opresji takie jak rasizm, seksizm czy przymus ekonomiczny ${ }^{6}$. Paradoks polega

${ }^{1}$ O. Hankivsky, R. Cormier, 2009, Intersectionality: Moving Women's Health Research and Policy Forward, Women's Health Research Network, Vancouver, s. 4.

2 Tamże, s. 3.

${ }^{3}$ Orzeczenie Trybunału Konstytucyjnego z dnia 9 marca 1988 r., U 7/87, OTK 1986-1995, cyt. za: H. Kaczmarczyk, 2016, Sprawiedliwość społeczna jako podstawa ładu społecznego, Studia i Materiały. Miscellanea Oeconomicae, nr 2, s. 60.

${ }^{4}$ I. Sierpowska, 2012, Pomoc społeczna jako administracja świadczqca. Studium administracyjnoprawne, Wolters Kluwer, Warszawa, s. 127-128.

5 Tamże, s. 128.

${ }^{6}$ M. Skóra, 2011, recenzja książki B. Thornton Dill, R.E. Zambrana (eds.), Emerging Intersections. Race, Class and Gender in Theory, Policy and Practice, Problemy Polityki Społecznej. Studia i Dyskusje, nr 15, s. 149. 
więc na tym, że z jednej strony polityka społeczna kreuje poczucie sprawiedliwości społecznej i zapobiega nierównościom społecznym, a z drugiej strony, poprzez sztywne rozwiązania instytucjonalne, niektóre nierówności utrwala ${ }^{7}$. Propozycją rozwiązania tego paradoksu, sformułowaną m.in. przez takie autorki, jak Thornton Dill i Zambrana ${ }^{8}$, jest zastosowanie perspektywy intersekcjonalnej, dzięki której programy polityki społecznej mogą być lepiej „skrojone na miarę”, czyli precyzyjniej dostosowane do potrzeb adresata. Intersekcjonalność polemizuje z pojęciami takimi jak standaryzacja, normatywność, uniwersalizm, rozwiązania odgórne. W swoich założeniach podejście intersekcjonalne skłania się ku: (a) decentralizacji, lokalnemu charakterowi polityki społecznej, (b) diagnozie opartej na doświadczeniach jednostek i małych zbiorowości, (c) selektywności rozumianej jako mądry kompromis między rozwiązaniami uniwersalnymi a wybiórczością typową dla liberalnych modeli polityki społecznej, (d) inicjatywom oddolnym, (e) aktywnemu zaangażowaniu w procesy decyzyjne adresatów polityk i programów społecznych.

\section{Geneza i specyfika analizy intersekcjonalnej}

Korzenie perspektywy intersekcjonalnej wywodzą się z wielokulturowego kontekstu amerykańskiego. Termin ,intersekcjonalność” (intersectionality) został sformułowany w 1989 r. przez amerykańską profesor prawa Kimberlé W. Crenshaw, twórczynię „krytycznej teorii rasy” (Critical Race Theory). Analiza intersekcjonalna zakłada przenikanie się i wzajemne jednoczesne oddziaływanie na siebie różnych kategorii społecznych, takich jak wiek, płeć, rasa, pochodzenie etniczne, klasa, status socjoekonomiczny, poziom wykształcenia, wyznanie religijne, orientacja seksualna, sprawność lub niepełnosprawność (fizyczna/intelektualna), geograficzne usytuowanie, przynależność do kultur/subkultur oraz innych. Istotą analizy intersekcjonalnej jest jednoczesne branie pod uwagę wielu zmiennych, które nakładając się na siebie i interferując ze sobą, tworzą zindywidualizowane biografie i, co za tym idzie, zindywidualizowane ryzyka socjalne. Innymi słowy, odchodząc od klasycznego ujęcia typowego dla polityków społecznych czy demografów, koncentrującego się na problemie (np. bezrobocie, ubóstwo, starzenie się populacji) lub pojedynczej kategorii społecznej (np. płeć - aktywność zawodowa kobiet, wiek - stan zdrowia ludności w wieku 65+, etniczność - status materialny Latynosów w USA itp.), omawiana w tym artykule perspektywa proponuje jednoczesne branie pod uwagę krzyżujących się ze sobą wielu kategorii społecznych, podkreślając złożoność procesu formowania się ludzkich tożsamości. W artykule tym intersekcjonalność zostanie omówiona jako metodologia badań naukowych oraz jako pewnego rodzaju idea przyświecająca tworzeniu polityk społecznych.

7 Tamże.

${ }^{8}$ B. Thornton Dill, R.E. Zambrana, 2009, Emerging Intersections. Race, Class and Gender in Theory, Policy, and Practice, Rutgers University Press, New Jersey, London. 
W Polsce podejście oparte na analizie intersekcjonalnej nie jest rozpowszechnione. Powodem może być relatywnie wysoki stopień społecznej homogeniczności. Pod kątem metodologii i postulatów wysuwanych pod adresem twórców polityki społecznej zbliżone badania prowadzone są nad kategorią gender w państwie opiekuńczym (gender \& welfare state). Badania nad kategorią gender w polityce społecznej podkreślają nierówny status kobiet i mężczyzn związany z partycypacją $\mathrm{w}$ takich obszarach, jak rynek pracy, ubezpieczenia społeczne, świadczenie usług opiekuńczych czy pełnienie funkcji reprodukcyjnych i rodzinotwórczych. „Feministyczna krytyka głównego nurtu badań nad polityką społeczną" ${ }^{10}$ postuluje zmianę instytucjonalną oraz podkreśla fakt, że instytucje są nacechowane płciowo ${ }^{11}$. W tym sensie jest koncepcyjnie zbliżona do perspektywy intersekcjonalnej, która zakłada, że instytucje utrwalają niektóre wymiary nierówności społecznych oraz reprodukują mechanizmy represji, takie jak ageizm, seksizm czy rasizm. Jednakże bezpośrednie zaadaptowanie analizy intersekcjonalnej w badaniach nad polityką społeczną nie jest w Polsce powszechne. W odróżnieniu od badań nad kategorią gender w polityce społecznej, perspektywa intersekcjonalna postuluje włączenie do analizy kilku kategorii społecznych jednocześnie, stąd do nurtu badań intersekcjonalnych zaliczyć można np. badanie nad stanem zdrowia psychicznego kobiet (lub mężczyzn) w wieku 65+ zamieszkujących obszary wiejskie o dochodzie nieprzekraczającym równowartości płacy minimalnej. Wówczas do analizy włączone zostają cztery kategorie jednocześnie: płeć, wiek, miejsce zamieszkania i status materialny. W trakcie prowadzenia badań może się okazać, że dodatkowe zmienne, takie jak poziom wykształcenia, stan cywilny lub dostęp (albo jego brak) do nowych technologii medialnych mogą w istotny sposób rzutować na rezultaty badania. Co więcej, analiza intersekcjonalna zachęca również do samorefleksyjności i świadomego społeczno-kulturowego usytuowania badacza (badaczy), z którego wynika pewien subiektywizm narracyjny i poznawczy.

Intersekcjonalność jako paradygmat badawczy całkowicie zmienia sposób, w jaki problemy społeczne są diagnozowane, doświadczane i postrzegane. Czyni to przede wszystkim poprzez odzwierciedlanie wielorakości i różnorodności doświadczeń przeżytych przez ludzi (lived experience) ${ }^{12}$. W tym sensie perspektywa inter-

9 P. Michoń, 2004, Płeć w modelach polityki społecznej, Problemy Polityki Społecznej. Studia i Dyskusje, nr 7, s. 75-87; D. Szelewa, 2013, Going Mainstream - Feminist Influence on Comparative Welfare State Research, [w:] Michoń P., Orczyk J., Żukowski M. (eds.), Facing the Challenges. Social Policy in Poland after 1990, Wydawnictwo Uniwersytetu Ekonomicznego w Poznaniu, Poznań, s. 50-62; A. Kurowska i in., 2016, Perspektywa gender w polityce społecznej, Wydawnictwo Naukowe UMK, Toruń

${ }^{10}$ D. Szelewa, Gender w polityce społecznej. Teoria i praktyka, Warszawskie Debaty o Polityce Społecznej, nr 4, 2012, Friedrich Ebert Stiftung i Fundacja Międzynarodowe Centrum Badań i Analiz.

${ }^{11}$ A. Kurowska i in., 2016, wyd. cyt.

12 J. Oxman-Martinez et al., 2002, Competing Conceptions of Conjugal Violence: Insights from an Intersectional Framework, Centre for Applied Family Studies, McGill University, cyt. za: O. Hankivsky, R. Cormier, 2009, wyd. cyt., s. 4. 
sekcjonalna ma pewne cechy wspólne z innym paradygmatem badawczym - z perspektywą cyklu życia. Perspektywa cyklu życia zwraca uwagę na to, że „scenariusze (cykle) życia stają się coraz bardziej zindywidualizowane i zdywersyfikowane, towarzyszą im coraz to nowe zagrożenia i nowe rodzaje ryzyka socjalnego, którym tradycyjny system zabezpieczenia socjalnego nie jest w stanie sprostać"13. W odróżnieniu od tradycyjnie rozumianej polityki społecznej, skoncentrowanej na problemach społecznych i ryzykach socjalnych, „nowe spojrzenie na politykę społeczną [...] zwraca uwagę na różnorodność przypadków oraz elastyczność scenariuszy życia, które powodują, że w dzisiejszych czasach trudno o przejrzystą cezurę czasową ludzkiej aktywności społecznej i zawodowej”"14.

W tradycyjnym podejściu do nauki o polityce społecznej „kategorie społeczne postrzegane są jako statyczne i stanowiące przyczynę pewnych zachowań, podczas gdy z perspektywy intersekcjonalnej kategorie są rezultatem zachowań oraz są nieustannie konstruowane, dekonstruowane i rekonstruowane"15. Są płynne, zmienne, uwarunkowane historycznie, społecznie i kulturowo, oddziałują zarówno na poziomie mikro-, jak i makrospołecznym ${ }^{16}$.

\section{Intersekcjonalność jako wyzwanie metodologiczne}

Metodologiczne podwaliny analizy intersekcjonalnej odwołują się do tak zwanej teorii kategorii rozmytych lub inaczej teorii zbiorów rozmytych (fuzzy set theory) ${ }^{17}$. Jej istotą jest wyróżnienie zjawiska zróżnicowania wewnątrzgrupowego, wewnątrz jednego zbioru (zbiorowości) posiadającego pewne cechy wspólne (within group diversity). Pojęcie zbioru rozmytego wywodzi się z matematyki i stanowi rozszerzenie klasycznej teorii zbiorów. Zostało sformułowane w latach 60. XX wieku. W kolejnych dekadach koncepcja kategorii rozmytych znalazła zastosowanie w metodologii badań społecznych, m.in. w psychologii ${ }^{18}$. Podczas gdy tradycyjnie w badaniach z obszaru socjologii stosuje się podejście oparte na kategoriach i zmiennych (variable oriented), teoria zbiorów rozmytych umożliwia operacjonalizację przy założeniu złożonej kompleksowości warunkowania przyczynowego. Istotnym założeniem analizy intersekcjonalnej jest zerwanie z uproszczoną supozycją mówiącym o tym, że każda zmienna (variable) lub każdy czynnik przyczynowo-skutkowy (causal fac-

${ }^{13}$ K. Zapędowska-Kling, 2017, Zastosowanie perspektywy cyklu życia w polityce społecznej i pracy socjalnej, Problemy Polityki Społecznej. Studia i Dyskusje, nr 36(1), s. 66.

${ }_{14}$ Tamże.

15 D. Staunæs, Where have all the subjects gone? Bringing together the concepts of intersectionality and subjectification, Nora, no. 11(2), 2003, s. 104, cyt. za: O. Hankivsky, R. Cormier, 2009, wyd. cyt., s. 5.

${ }^{16}$ O. Hankivsky, R. Cormier, 2009, wyd. cyt., s. 5.

17 A.-M. Hancock, 2007, When multiplication doesn't equal quick addition: Examining intersectionality as a research paradigm, Perspectives on Politics, no. 5(1), s. 63-78.

${ }_{18}$ C. Noworol, 2013, Heurystyki kategorii rozmytych w koncepcji pomiaru psychologicznego, Wydawnictwo Uniwersytetu Jagiellońskiego, Kraków. 
tor) może zostać wyodrębniony, wyizolowany od pozostałych ${ }^{19}$. W świetle perspektywy intersekcjonalnej wszystkie zmienne i wszystkie czynniki przyczynowo-skutkowe oddziałują na siebie, współkształtują siebie nawzajem i są od siebie współzależne.

Teoria zbiorów rozmytych dopuszcza zjawisko zróżnicowania wewnątrzgrupowego. Zróżnicowanie wewnątrz jednej, z pozoru dość jednolitej grupy społecznej bywa czasami większe niż zróżnicowanie pomiędzy dwiema różnymi grupami. Prawidłowość tę zauważył Varcoe i in., który twierdzi, że „w koncepcję zdrowia kobiet wpisane jest paradoksalne wyzwanie polegające na tym, że zróżnicowanie pomiędzy samymi kobietami jest często większe niż zróżnicowanie pomiędzy kobietami [...] a mężczyznami" 20 .

$\mathrm{Z}$ metodologicznego punktu widzenia analiza intersekcjonalna bywa krytykowana jako relatywistyczna i trudna do operacjonalizacji ${ }^{21}$. W świecie nauki dominują spolaryzowane przeciwieństwa (kobiety-mężczyźni, młodzi-starzy, aktywni zawodowo-bezrobotni, chorzy-zdrowi itp.), a „polikategorie” (multiple categories) wprowadzają metodologiczny chaos. Jednym z najbardziej kompleksowych opracowań poświęconych metodologii intersekcjonalnej jest tabelaryczne zestawienie A.-M. Hancock, która porównuje tzw. ujęcie unitarne (unitary) z ujęciem wielokrotnym (multiple) i intersekcjonalnym (intersectional). Podstawowe wyznaczniki analizy intersekcjonalnej to: (a) zaadresowanie w badaniu więcej niż jednej kategorii społecznej, (b) przyjęcie, że wszystkie zaadresowane kategorie mają równe znaczenie, a relacje między przyjętymi kategoriami stanowią otwarte pytanie empiryczne, (c) konceptualizacja kategorii zakłada występowanie dynamicznych interakcji między czynnikami personalnymi i instytucjonalnymi, (d) poziom analizy jest zintegrowany, bierze pod uwagę jednocześnie czynniki indywidualne $\mathrm{i}$ instytucjonalne, (e) w metodologii wykorzystuje się jednocześnie metody empiryczne i teoretyczne ${ }^{22}$.

Do tej pory nie powstało kompleksowe opracowanie dotyczące praktycznych wskazówek i metod zaaplikowania analizy intersekcjonalnej w badaniach jakościowych i ilościowych. Literatura nad intersekcjonalnością oferuje jednak wiele sugestii dotyczących sposobu podejścia i logiki konstruowania badań. Jedna z metod wpisująca się w szeroko rozumianą filozofię intersekcjonalną zakłada „oddolną” (w odróżnieniu od „odgórnej”) organizację badań, dzięki której przedmiot badań jest jednocześnie ich aktywnym uczestnikiem. Chodzi tutaj przede wszystkim o tzw. metodologię uczestniczącą (participatory research method) ${ }^{23}$, która niekoniecznie musi

19 A.-M. Hancock, 2007, wyd. cyt., s. 73.

${ }^{20}$ C. Varcoe, O. Hankivsky, M. Morrow, 2007, Beyond gender matters: An introduction [w:] Hankivsky O., Varcoe C. (eds.), Women's Health in Canada. Critical Theory, Policy and Practice, University of Toronto Press, Toronto, s. 12.

${ }^{21}$ J. Oxman-Martinez et al., 2002, wyd. cyt., za: O. Hankivsky, R. Cormier, 2009, wyd. cyt., s. 19.

${ }^{22}$ A.-M. Hancock, 2007, wyd. cyt., s. 64.

23 J. Bergold, S. Thomas, 2012, Participatory research methods: A methodological approach in motion, Forum: Qualitative Social Research, vol. 13(1), Art. 30. 
przyjmować formę obserwacji uczestniczącej. Formą uwzględnienia przedmiotu badań jako aktywnego uczestnika może być np. zastosowanie „perspektywy końcowego odbiorcy” (end user perspective) lub „podejścia skoncentrowanego na użytkowniku" (user-centered approach) we wszelkich obszarach związanych z projektowaniem i planowaniem dóbr i usług (np. w takich obszarach tematycznych, jak podaż usług społecznych, dostęp do służby zdrowia, projektowanie technologii asystujących dla osób niepełnosprawnych, implementacja rozwiązań z dziedziny gerontechnologii dla seniorów itp.).

\title{
4. Dyskryminacja wielokrotna
}

\author{
Tożsamości ludzi składają się z wielu komponentów, sa funkcjami przynależności \\ i identyfikacji z wieloma grupami i kręgami. To złożone, wielowymiarowe całości, \\ z których $w$ zależności od sytuacji niektóre identyfikacje czy role stają się ważniejsze, \\ ale nigdy nie zawieraja w sobie wielowymiarowości tożsamości ${ }^{24}$.
}

Perspektywa intersekcjonalna podkreśla złożoność ludzkich tożsamości, na które składają się różne komponenty. Komponenty te są pochodną przynależności do rozmaitych kategorii i grup społecznych. Na ukonstytuowanie się tożsamości jednostki wpływają takie czynniki, jak płeć, wiek, profesja, stan cywilny, poziom wykształcenia, status materialny, miejsce zamieszkania, przynależność do mniejszych lub większych wspólnot (sąsiedzkich, religijnych, kulturowych), stan zdrowia (rozumiany w wymiarze fizycznym i psychicznym), relacje rodzinne, orientacja seksualna, a nawet takie pozornie nieistotne zmienne, jak zamiłowania, gusta i hobby. Skoro jednostki ludzkie przynależą do wielu kategorii i grup społecznych jednocześnie, a niektórych ról społecznych nie da się jasno odgraniczyć (np. rola kobiety - partnerki - matki - pracownicy), socjologowie zwracają uwagę na zjawisko dyskryminacji wielokrotnej, które polega na jednoczesnej przynależności do dwóch lub więcej kategorii wykluczanych lub gorzej traktowanych w danej społeczności lub kulturze. Przykładami mogą być: niepełnosprawny imigrant, doświadczający zarówno ksenofobii, jak i barier architektonicznych utrudniających codzienne funkcjonowanie; starsza, czarnoskóra kobieta, doświadczająca jednocześnie przejawów rasizmu, seksizmu i ageizmu; uboga, niewykształcona rodzina zamieszkująca na wsi, nieposiadająca kompetencji medialnych (wykluczenie cyfrowe) i tym samym mająca trudności z zaistnieniem na rynku pracy. Przykłady można by mnożyć. Jak zauważają Cieślikowska i Sarata, „grupy mniejszościowe, podobnie jak większościowe, same w sobie także nie są homogeniczne; w związku z ich wewnętrznym zróżnicowaniem w nich także mają miejsce napięcia związane $\mathrm{z}$ «uprzywilejowaniem» i wykluczeniem w ramach mniejszości, ponieważ przynależność do różnych grup jest społecz-

${ }^{24}$ D. Cieślikowska, N. Sarata, 2012, Dyskryminacja wielokrotna - historia, teorie, przegląd badań, Fundacja Fundusz Współpracy i Towarzystwo Współpracy Antydyskryminacyjnej, s. 2, http:// www.tea.org.pl/userfiles/file/Wielokrotna.pdf (dostęp: 22.08.2017). 
nie wartościowana - w mniejszościowej grupie kobiet bycie białą, heteroseksualną kobietą o wysokim statusie materialnym daje zdecydowanie inną, lepszą pozycję, niż bycie «inną» etnicznie, dotkniętą ubóstwem kobietą z niepełnosprawnością"25. Autorki rozróżniają trzy różne typy dyskryminacji: (a) wielokrotna (w wąskim rozumieniu) - gdy „osoba jest dyskryminowana ze względu na przynależność do różnych grup, ale doświadcza tej dyskryminacji oddzielnie, w różnym czasie"26, (b) sumowana/wiązana - gdy osoba doświadcza różnych przesłanek dyskryminacji w tym samym czasie lub w jednej sytuacji, (c) intersekcjonalna/krzyżowa - gdy różne przesłanki wykluczenia i dyskryminacji krzyżują się, wchodzą ze sobą w interakcje i trudno odgraniczyć jej przyczyny ${ }^{27}$. Co ciekawe, ,ponieważ jednostki przynależą do więcej niż jednej społeczności i mogą identyfikować się z więcej niż jedną grupą społeczną, mogą jednocześnie doświadczać zjawiska dyskryminacji i uprzywilejowania" 28 .

Programy i strategie polityki społecznej rzadko adresują problem dyskryminacji wielokrotnej. Z reguły koncentrują się na jednym wymiarze „podatności na zagrożenie" (vulnerability), jakim jest bezrobocie, starość, choroba, status samotnej matki, przynależność do rodziny wielodzietnej, uzależnienie i tym podobne ryzyka socjalne. Dobrym przykładem programu realizowanego przez Ministerstwo Pracy i Polityki Społecznej była kampania zatytułowana „Poszukiwana 45+: rzetelność, zaangażowanie, doświadczenie”. Program ten został ,skrojony na miarę” w oparciu o trzy kategorie jednocześnie: płeć, wiek i status osoby bezrobotnej. W myśl perspektywy intersekcjonalnej wyodrębnił grupę społeczną szczególnie narażoną na ryzyko socjalne, jakim jest brak posiadania zatrudnienia. Twórcy programu słusznie zauważyli, że w przypadku kobiet, wskutek negatywnego oddziaływania ageizmu i stereotypów, trudności ze znalezieniem pracy pojawiają się relatywnie wcześniej niż w przypadku mężczyzn. Czynnikiem narażającym na wykluczenie z rynku pracy jest współistnienie kryterium płci i wieku. Inne programy rządowe, których celem jest aktywizacja zawodowa, z reguły adresowane są do populacji w wieku 50/55+ (np. program „Solidarność pokoleń. Działania dla zwiększenia aktywności zawodowej osób w wieku 50+"). Wymieniony wyżej dobry przykład wpisuje się w nurt perspektywy intersekcjonalnej, gdyż całościowo analizuje sytuację kobiet w konkretnych realiach ekonomiczno-społeczno-kulturowych. W realiach tych kobiety po 45. roku życia traktowane są jako bezużyteczne pod kątem reprodukcyjnym, niewystarczająco dyspozycyjne zawodowo ze względu na obowiązki rodzinne, wyłamujące się ze standardów urody typowych dla kultu młodości obowiązującego w kulturze świata zachodniego, a nawet, co gorsza, niestabilne emocjonalnie ze względu na zmiany hormonalne typowe dla okresu menopauzalnego. Jednocześnie mężczyzna

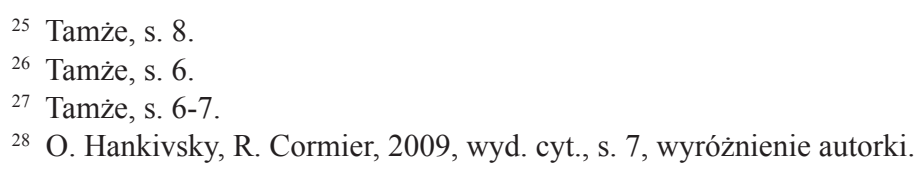


w wieku 45+ może być postrzegany jako doświadczony, rzetelny, dyspozycyjny, $\mathrm{z}$ ustabilizowaną sytuacją rodzinną i materialną.

Przytoczone przykłady wskazują na potrzebę zaadresowania problemu dyskryminacji wielokrotnej przez twórców polityki społecznej. Zjawisko to zostało zdiagnozowane i opisane w 2009 r. w odniesieniu do porządku prawnego Unii Europejskiej. Raport opracowany przez Europejską Sieć Ekspertów Prawnych w Dziedzinie Równości Płci (The European Network of Legal Experts in the Field of Gender Equality), odwołując się do paradygmatu intersekcjonalności, wskazuje na potrzebę bezpośredniego zaadresowania problemu dyskryminacji wielokrotnej, funkcjonującej $\mathrm{w}$ terminologii unijnej pod nazwą multiple discrimination, w dyrektywach unijnych. Aktualnie obowiązujące dyrektywy antydyskryminacyjne z 2000 r. nawiązują pośrednio do zjawiska intersekcji między dyskryminacją ze względu na płeć a innymi formami dyskryminacji ${ }^{29}$.

\section{Intersekcjonalność w badaniach nad zdrowiem publicznym}

Researchers, policy-makers, and practitioners are recognizing that women's health and experiences are shaped not only by sex and gender, but also by other factors such as race, class, culture, income, education, age, ability, sexual education, immigration status, ethnicity, indigeneity, geography, and so on.

[Naukowcy, decydenci polityczni i praktycy zaczynają dostrzegać, że stan zdrowia i doświadczenia kobiet są uwarunkowane nie tylko poprzez płeć biologiczną i kulturową, ale również przez inne czynniki, takie jak rasa, klasa, kultura, dochód, wykształcenie, wiek, (nie)pełnosprawność, orientacja seksualna, status imigracyjny, etniczność, „tubylczość”, położenie geograficzne oraz inne - thum. aut. $]^{30}$.

Badania nad zdrowiem publicznym oraz badania w obszarze epidemiologii są niezwykle istotne z punktu widzenia priorytetów polityki społecznej - po pierwsze, ze względu na zmieniającą się strukturę społeczną wynikającą ze starzenia się populacji, po drugie, z uwagi na wysokie koszty związane z finansowaniem ochrony zdrowia. Mimo że w przypadku ustalania przewidywalnej średniej długości trwania życia statystyki z reguły dokonują podziału według kategorii płci biologicznej (sex), zważywszy na różnice w wartościach dożywanego wieku przez kobiety i przez mężczyzn, w przypadku badań nad stanem zdrowia danej populacji podejście oparte na analizie intersekcjonalnej wydaje się bardziej adekwatne. Na przykład badania epidemiologiczne nad HIV/AIDS wykazują, że specyfika zachorowań jest zupełnie inna np. w Kanadzie, gdzie trzykrotnie więcej zachorowań odnotowuje się wśród mężczyzn, i w subsaharyjskim regionie Afryki, gdzie zarażonych jest więcej kobiet.

29 S. Burri, D. Schiek, 2009, Multiple Discrimination in EU Law. Opportunities for Legal Responses to Intersectional Gender Discrimination?, European Network of Legal Experts in the Field of Gender Equality, European Commission, http://ec.europa.eu/justice/gender-equality/files/multiple discriminationfinal7september2009_en.pdf(dostęp: 07.09.2017).

${ }^{30}$ O. Hankivsky, R. Cormier, 2009, wyd, cyt., s. 1. 
Zdaniem badaczy ${ }^{31}$ to czynniki społeczno-środowiskowe, takie jak ubóstwo, przemoc domowa, ekspozycja na systemowy patriarchat, przyczyniają się do wysokiego współczynnika zachorowań wśród kobiet w Afryce ${ }^{32}$.

Pisząc o zdrowiu publicznym w kontekście polityki społecznej, należy wspomnieć o problemie niepełnosprawności i sposobach wspierania osób niepełnosprawnych przez polityki państwa. Kategoria „osoby niepełnosprawne”, a nawet „niepełnosprawne kobiety” czy „niepełnosprawni mężczyźni”, jest bardzo szeroka i inkluzywna. Inaczej kształtują się wyzwania związane z niepełnosprawnością w dużych aglomeracjach miejskich, inaczej na obszarach wiejskich. Inaczej subiektywnie doświadczają niepełnosprawności osoby ubogie niż osoby dobrze sytuowane. Innych programów i strategii wymaga problem niepełnosprawności towarzyszący procesowi starzenia się i związanej z nią niesamodzielności, a innych kwestia niepełnosprawności wśród dzieci i młodzieży szkolnej, wśród ludzi młodych, wyrażających gotowość do aktywności zawodowej.

Na Zachodzie od wielu lat uznaje się mnogość determinantów społeczno-kulturowych wpływających na stan zdrowia populacji. Dla przykładu, Agencja Zdrowia Publicznego Kanady w latach 90. XX wieku wyszczególniła dwanaście czynników mających wpływ na zdrowie. Czynniki te można podzielić na społeczne, kulturowe, środowiskowe, genetyczne i biologiczne ${ }^{33}$. Nowsze próby kategoryzacji obejmują podział czynników na poziom makro, w którego skład wchodzi płeć biologiczna, płeć kulturowa, klasa, rasa, etniczność, status imigracyjny, położenie geograficzne i wiek; poziom mezo, na który składa się dostęp do rozmaitych zasobów, takich jak zatrudnienie, edukacja, opieka przedszkolna, służba zdrowia lub bezpieczne sąsiedztwo; a także poziom mikro, do którego zaliczyć można zbiór zachowań i nawyków, takich jak zdrowa dieta, aktywny styl życia, sport, skłonności do używek i nałogów $^{34}$. W dzisiejszych czasach geopolitycznego niepokoju, w związku z dużą mobilnością społeczną, należy również pamiętać o nieuprzywilejowanej pozycji imigrantów i uchodźców, którzy skarżą się na niesatysfakcjonujący stan zdrowia, a przede wszystkim na brak dostępu do informacji, usług społecznych i zdrowotnych dostępnych często jedynie w oparciu o kryterium obywatelstwa.

Podejście intersekcjonalne w obszarze epidemiologii i zdrowia publicznego zakłada precyzyjniejsze określanie grup docelowych programów usług i badań. To

${ }^{31}$ Zob. L. Osarenren, 2008, Africa: Tradition at the heart of violence against women and girls, Pambazuka News. Weekly Forum for Social Justice in Africa, http://allafrica.com/stories/200803061047. html (dostęp: 07.09.2017); Światowa Organizacja Zdrowia, 2004, Violence Against Women and HIV/ AIDS: Critical Intersections. Intimate Partner Violence and HIV/AIDS, Information Bulletin Series, no. 1, http://www.who.int/hac/techguidance/pht/InfoBulletinIntimate PartnerViolenceFinal.pdf (dostęp: 02.09.2017).

32 O. Hankivsky, R. Cormier, 2009, wyd, cyt., s. 1.

33 Tamże.

34 C. Benoit, L. Shumka, 2008, Why Gender Matters: Extending the Health Determinants Framework to Better Understand Girls' and Women's Health, Women's Health Research Network, Vancouver, s. 18-19, cyt. za: O. Hankivsky, R. Cormier, 2009, wyd. cyt., s. 12-13. 
przekonanie, że dzięki rozumieniu mnogości czynników wpływających na stan zdrowia jednostki można bardziej ekonomicznie gospodarować nakładami finansowymi przeznaczonymi na ochronę zdrowia. Cel ten można osiągnąć np. poprzez organizację badań przesiewowych skierowanych nie tylko do osób starszych rozumianych jako ogół, ale badań przesiewowych np. dla kobiet w wieku 55-65 lat zamieszkujących obszary wiejskie. Każdorazowe określenie grupy docelowej powinno zostać poprzedzone badaniem społeczności z zastosowaniem analizy intersekcjonalnej, by dzięki współpracy nauki z decydentami politycznymi szczebla państwowego i samorządowego możliwie jak najrzetelniej określić parametry grup szczególnego ryzyka.

\section{Intersekcjonalność w badaniach nad pracą socjalną}

Niewiele badań naukowych poświęcono kwestii zastosowania analizy intersekcjonalnej w pracy socjalnej. Temat ten wydaje się wciąż niezbadany, szczególnie w warunkach nauki polskiej. Jednym z większych projektów naukowo-badawczych realizowanych we współpracy międzynarodowej, który odwołuje się do metodologii analizy intersekcjonalnej, jest projekt dotyczący zapobiegania przemocy rówieśniczej (tytuł projektu - Implementation Guidelines for Intersectional Peer Violence Preventive Work, realizacja - 2010-2011 rok, źródło finansowania - Komisja Europejska, program Grundtvig) $)^{35}$. Mimo iż projekt sensu stricto dotyczy kształcenia osób dorosłych i w zasadzie można go usytuować na pograniczu pedagogiki społecznej i pracy socjalnej, wiele zawartych w finalnym raporcie i podręczniku wniosków jest wartościowych i adekwatnych w odniesieniu do specyfiki pracy pracownika socjalnego, szczególnie w społecznościach zróżnicowanych kulturowo. Projekt zwraca uwagę na potrzebę wrażliwości edukatorów/pracowników socjalnych na istniejące współpowiązania pomiędzy rasą, płcią i klasą społeczną ${ }^{36}$. Znajomość podstaw perspektywy intersekcjonalnej jest szczególnie pożądana i przydatna w zawodzie nauczyciela, który obcuje z dziećmi i młodzieżą. Przyjmowane przez szkoły strategie prewencji antyprzemocowej, takie jak „zero tolerancji”, a także „etykietowanie" uczniów w odniesieniu do ich pochodzenia/rasy/zawodu rodziców/miejsca zamieszkania skutkuje tradycyjnym zunifikowanym postrzeganiem grupy rówieśniczej jako stosunkowo homogenicznej zbiorowości. Perspektywa intersekcjonalna wzbogaca tę tendencję o świadomość różnorodnych środowisk i kontekstów, z jakich wywodzą się uczniowie i wynikających z nich różnorodnych potrzeb i możliwości, jakie demonstrują. W ramach praktycznych wskazówek skierowanych pod adresem edukatorów i pracowników socjalnych wymienić można m.in.: (a) pracę

35 O. Stuve, E. Scambor, M. Fischer et al., Handbook International Peer Violence Prevention, Implementation Guidelines for an Intersectional Peer Violence Preventive Work (IGIV), 2011, http:// vmg-steiermark.at/sites/maennerberatung.mur.at/files/forschungdownloads/handbook_intersectional_ violence_prevention.pdf (dostęp: 29.08.2017).

${ }^{36}$ Tamże. 
w małych grupach, (b) metodę badań typu fieldwork lub obserwacji uczestniczącej, (c) sfokusowanie na potrzebach i zainteresowaniach uczestniczek i uczestników badań, (d) dbałość o spokojną, miłą atmosferę współpracy, komfort i poczucie bezpieczeństwa, (e) nastawienie na zadawanie pytań, (f) skoncentrowanie na codziennych doświadczeniach uczestniczek i uczestników badań, (g) podejście kontrintuicyjne, samorefleksyjność badacza, umiejętność obiektywnego zrobienia „kroku wstecz” i nieulegania wyuczonym, stereotypowym reakcjom i odruchom ${ }^{37}$.

\section{Intersekcjonalność w badaniach nad polityką społeczną}

Zastosowanie perspektywy intersekcjonalnej w badaniach nad polityką społeczną ma dwa podstawowe cele. Pierwszy z nich, w myśl założeń nowego instytucjonalizmu, uświadamia występowanie dynamicznych interakcji pomiędzy jednostkami a aktorami instytucjonalnymi, a poprzez to renegocjuje znaczenie takich terminów, jak ,skuteczne” i „nieskuteczne” polityki i programy społeczne. Analiza intersekcjonalna pozwala dostrzec sposoby i kierunki oddziaływania instytucji na jednostki i jednostek na instytucje. W ramach ewaluacji strategii i programów społecznych nakazuje zadawać pytania: „która grupa odbiorców najbardziej/ najmniej skorzystała i dlaczego?”, ,względem których grup społecznych działania okazały się skuteczne/nieskuteczne?" i tym podobne. Drugim celem, jaki przyświeca zastosowaniu intersekcjonalności w polityce społecznej, jest optymalizacja nakładów finansowych poprzez precyzyjniejsze określanie grupy docelowej odbiorców. Branie pod uwagę kilku zmiennych (kategorii) jednocześnie daje czasami zupełnie inny obraz danego rozwiązania systemowego. Na przykład, amerykańskie przepisy określają aktualnie 66 lat jako oficjalny wiek emerytalny (dla osób urodzonych w latach 1943-1954). Wiek emerytalny jest równy dla wszystkich. W praktyce jednak okazuje się, że długość okresu pobierania świadczeń emerytalnych różni się istotnie w zależności od grupy społecznej i średniej długości dożywanego przez nią wieku. Średnia długość trwania życia w chwili urodzenia wynosi w USA 77,1 lat w przypadku białych mężczyzn i 71,7 lat w przypadku czarnoskórych mężczyzn, 81,7 w przypadku białych kobiet i 78,0 lat w przypadku czarnoskórych kobiet ${ }^{38}$. Analiza z uwzględnieniem trzech kategorii - płci, rasy i wieku wskazuje, że w świetle aktualnie obowiązujących przepisów emerytalnych czarnoskóry Amerykanin będzie pobierał świadczenia emerytalne średnio o dziesięć lat krócej (5,7 lat) niż biała Amerykanka (15,7 lat). Dzięki intersekcjonalności zmienia się optyka postrzegania funkcjonowania systemu. Możliwe staje się wyodrębnienie grup potencjalnie, lub faktycznie, uprzywilejowanych i poszkodowanych. Inny przykład wskazuje na to, że „zestawienie [...]

37 Tamże, s. 30-31.

38 J.M. Ortman, V.A. Velkoff, H. Hogan, 2014, An Aging Nation: The Older Population in the United States. Population Estimates and Projections, U.S. Census Bureau, https://www.census.gov/ prod/2014pubs/p25-1140.pdf (dostęp: 29.08.2017). 
trzech zmiennych (płeć, wiek, rasa) może wskazywać na istotne kontrasty w ocenie jakości życia. Wystarczy przeanalizować stopień zagrożenia ubóstwem seniorów podczas gdy w grupie: (a) mężczyzn, (b) rasy białej, (c) w przedziale wiekowym 65-74 lata poziom ubóstwa wynosi 4,5\%, w grupie: (a) kobiet, (b) czarnoskórych, (c) powyżej 75. roku życia poziom ten okazuje się aż dziesięciokrotnie wyższy"39. Wskazane przykłady uświadamiają, jak nieprecyzyjne określenia stosowane są w dyskursie publicznym - mówi się np. o „zagrożeniu ubóstwem seniorów”, czyli bardzo zdywersyfikowanej i szeroko pojętej populacji osób w wieku 65+. Analiza intersekcjonalna, zakładając występowanie zjawiska zróżnicowania wewnątrzgrupowego, pochyla się nad zbiorowościami i umożliwia wychwycenie niuansów związanych $\mathrm{z}$ oddziaływaniem instytucji na jednostki. Odcina się od generalizacji i umożliwia skuteczniejszą współpracę sektora nauki i sektora administracji państwowej.

Innym potencjalnym obszarem zastosowania analizy intersekcjonalnej w polityce społecznej jest ewaluacja strategii i programów społecznych. Na przykład przy ocenie programu aktywizującego osoby bezrobotne na rynku pracy nakazuje się przeprowadzenie statystyk w oparciu o kilka kategorii jednocześnie. Dzięki temu twórcy programu uzyskują precyzyjniejszą informację zwrotną - nie tylko o tym, jaki procent uczestników programu został przywrócony na rynek pracy, lecz także inne: (a) jaki był przedział wiekowy beneficjentów?, (b) jaki był poziom i profil wykształcenia beneficjentów?, (c) skąd pochodzili beneficjenci?, (d) skąd uzyskali wiedzę na temat programu?, (e) czy z programu skorzystało więcej kobiet, czy mężczyzn?, (f) jaka grupa społeczna nie skorzystała z programu w ogóle?, i tym podobne. Dzięki perspektywie intersekcjonalnej istnieje możliwość dostrzeżenia luk i niedoskonałości w sposobie realizacji programów społecznych.

\section{Podsumowanie}

Współczesna nauka popularyzuje holistyczne podejście do człowieka w obszarach takich jak służba zdrowia ${ }^{40}$, edukacja ${ }^{41}$, gerontologia społeczna ${ }^{42}$ i praca socjalna ${ }^{43}$. Analogiczne „całościowe” podejście do polityki społecznej wiąże się z propozycją włączenia elementów analizy intersekcjonalnej do procesu diagnozy problemów

${ }^{39}$ U.S. General Accounting Office, Elderly Americans: Health, Housing, and Nutrition Gaps Between the Poor and Nonpoor, Government Printing Office, Washington 1992, cyt. za: K. Zapędowska-Kling, 2016, Polityka społeczna wobec osób starszych w USA $i$ w Szwecji. Wnioski dla Polski, Wydawnictwo Uniwersytetu Łódzkiego, Łódź, s. 40.

${ }^{40}$ M. Greener, 2013, The Holistic Health Handbook, Sheldon Press, London.

${ }^{41}$ M. Ben-Peretz, 2009, Policy-making in Education. A Holistic Approach in Response to Global Changes, Rowman \& Littlefield Education, Plymouth.

${ }^{42}$ L. Hyer, 2014, Psychological Treatment of Older Adults. A Holistic Model, Springer Publishing Company, New York.

43 J.T. Pardeck, F.K.O. Yuen (eds.), 1999, Family Health. A Holistic Approach to Social Work Practice, Greenwood Publishing Group, Westport, London. 
społecznych. Świadomość złożoności procesów przyczynowo-skutkowych i mnogości oddziałujących na siebie determinantów zmian jest kluczową refleksją analizy intersekcjonalnej. Mimo iż wciąż wymaga dopracowania aparatu pojęciowego i możliwych do zaaplikowania w praktyce metod badawczych, co do zasady perspektywa intersekcjonalna wnosi do polityki społecznej istotne wartości: samorefleksyjność, podejście skoncentrowane na przedmiocie badań, aktywne zaangażowanie przedmiotu badań w proces badawczy, świadomość obopólnego oddziaływania na siebie instytucji i jednostek, świadomość istnienia instytucjonalnych mechanizmów opresji i władzy oraz wrażliwość na występowanie zjawiska dyskryminacji wielokrotnej. Przeprowadzona analiza oraz przegląd literatury podkreśliły potencjalne korzyści wynikające z zaadaptowania analizy intersekcjonalnej nie tylko na etapie planowania polityk społecznych, lecz również na etapie realizacji i ewaluacji strategii oraz programów z zakresu epidemiologii i zdrowia publicznego, gerontologii, edukacji czy pracy socjalnej. Analogicznie do unijnej koncepcji gender mainstreaming, która polega na włączeniu perspektywy płci do głównego nurtu polityki, w ramach konkluzji nie sposób nie zaproponować nowej strategii, roboczo nazwanej intersectionality mainstreaming, która polegałaby na zaadaptowaniu perspektywy intersekcjonalnej w procesach polityczno-twórczych - szczególnie w obszarze polityki społecznej, tak ściśle związanej z jakością życia człowieka.

\section{Literatura}

Benoit C., Shumka L., 2008, Why Gender Matters: Extending the Health Determinants Framework to Better Understand Girls' and Women's Health, Women's Health Research Network, Vancouver.

Ben-Peretz M., 2009, Policy-making in Education. A Holistic Approach in Response to Global Changes, Rowman \& Littlefield Education, Plymouth.

Bergold J., Thomas S., 2012, Participatory research methods: A methodological approach in motion, Forum: Qualitative Social Research, vol. 13(1), Art. 30.

Burri S., Schiek D., 2009, Multiple Discrimination in EU Law. Opportunities for Legal Responses to Intersectional Gender Discrimination?, European Network of Legal Experts in the Field of Gender Equality, Komisja Europejska, http://ec.europa.eu/justice/genderequality/files/multiplediscriminationfinal7september2009_en.pdf (dostęp: 07.09.2017).

Cieślikowska D., Sarata N., 2012, Dyskryminacja wielokrotna - historia, teorie, przeglad badań, Fundacja Fundusz Współpracy i Towarzystwo Współpracy Antydyskryminacyjnej, http://www.tea. org.pl/userfiles/file/ Wielokrotna.pdf (dostęp: 22.08.2017).

Greener M., 2013, The Holistic Health Handbook, Sheldon Press, London.

Hancock A.-M., 2007, When multiplication doesn't equal quick addition: Examining intersectionality as a research paradigm, Perspectives on Politics, no. 5(1), s. 63-78.

Hankivsky O., Cormier R., 2009, Intersectionality: Moving Women's Health Research and Policy Forward, Women's Health Research Network, Vancouver.

Hyer L., 2014, Psychological Treatment of Older Adults. A Holistic Model, Springer Publishing Company, New York.

Kaczmarczyk H., 2016, Sprawiedliwość społeczna jako podstawa ładu społecznego, Studia i Materiały. Miscellanea Oeconomicae, nr 2/2016, s. 55-65. 
Kurowska A. i in., 2016, Perspektywa gender w polityce społecznej, Wydawnictwo Naukowe UMK, Toruń.

Michoń P., 2004, Płeć w modelach polityki społecznej, Problemy Polityki Społecznej. Studia i Dyskusje, $\mathrm{nr}$ 7, s. 75-87.

Noworol C., 2013, Heurystyki kategorii rozmytych w koncepcji pomiaru psychologicznego, Wydawnictwo Uniwersytetu Jagiellońskiego, Kraków.

Ortman J.M., Velkoff V.A., Hogan H., 2014, An Aging Nation: The Older Population in the United States. Population Estimates and Projections, U.S. Census Bureau, https://www.census.gov/prod/ 2014pubs/p25-1140.pdf (dostęp: 29.08.2017).

Osarenren, L., 2008, Africa: Tradition at the heart of violence against women and girls, Pambazuka News. Weekly Forum for Social Justice in Africa, http://allafrica.com/stories/200803061047.html (dostęp: 07.09.2017).

Oxman-Martinez J. et al., 2002, Competing Conceptions of Conjugal Violence: Insights from an Intersectional Framework, Centre for Applied Family Studies, McGill University.

Pardeck J.T., Yuen F.K.O. (eds.), 1999, Family Health. A Holistic Approach to Social Work Practice, Greenwood Publishing Group, Westport, London.

Piątek K., 2016, Polityka społeczna jako sposób rozwiq̨ywania problemów społecznych na poziomie lokalnym - przypadek przestępczości, [w:] Auleytner J. (red.), Krajowe i międzynarodowe konteksty polityki spolecznej, Warszawa, s. 374-390.

Sierpowska I., 2012, Pomoc społeczna jako administracja świadcząca. Studium administracyjnoprawne, Wolters Kluwer, Warszawa.

Skóra M., 2011, recenzja książki B. Thornton Dill, R. Enid Zambrana (eds.), Emerging Intersections. Race, Class and Gender in Theory, Policy and Practice, Problemy Polityki Społecznej. Studia i Dyskusje, nr 15, s. 147-156.

Staunæs D., 2003, Where have all the subjects gone? Bringing together the concepts of intersectionality and subjectification, Nora, no. 11(2), s. 101-110.

Stuve O., Scambor E., Fischer M. et al., 2011, Handbook International Peer Violence Prevention, Implementation Guidelines for an Intersectional Peer Violence Preventive Work (IGIV), http:// vmg-steiermark.at/sites/maennerberatung.mur.at/ files/forschungdownloads/handbook_intersectional_violence_prevention.pdf (dostęp: 29.08.2017).

Szelewa D., 2012, Gender w polityce społecznej. Teoria i praktyka, Warszawskie Debaty o Polityce Społecznej, nr 4, Friedrich Ebert Stiftung i Fundacja Międzynarodowe Centrum Badań i Analiz.

Szelewa D., 2013, Going Mainstream - Feminist Influence on Comparative Welfare State Research, [w:] Michoń P., Orczyk J., Żukowski M. (eds.), Facing the Challenges. Social Policy in Poland after 1990, Wydawnictwo Uniwersytetu Ekonomicznego w Poznaniu, Poznań, s. 50-62.

Światowa Organizacja Zdrowia, 2004, Violence Against Women and HIV/AIDS: Critical Intersections. Intimate Partner Violence and HIV/AIDS, Information Bulletin Series, no. 1, http://www.who.int/ hac/techguidance/pht/InfoBulletinIntimate PartnerViolenceFinal.pdf (dostęp: 02.09.2017).

Thornton Dill B., Zambrana R.E., 2009, Emerging Intersections. Race, Class and Gender in Theory, Policy, and Practice, Rutgers University Press, New Jersey, London.

U.S. General Accounting Office, 1992, Elderly Americans: Health, Housing, and Nutrition Gaps Between the Poor and Nonpoor, Government Printing Office, Washington.

Varcoe C., Hankivsky O., Morrow M., 2007, Beyond gender matters: An introduction, [w:] Hankivsky O., Varcoe C. (eds.), Women's Health in Canada. Critical Theory, Policy and Practice, University of Toronto Press, Toronto.

Zapędowska-Kling K., 2016, Polityka społeczna wobec osób starszych w USA i w Szwecji. Wnioski dla Polski, Wydawnictwo Uniwersytetu Łódzkiego, Łódź, s. 40.

Zapędowska-Kling K., 2017, Zastosowanie perspektywy cyklu życia w polityce społecznej i pracy socjalnej, Problemy Polityki Społecznej. Studia i Dyskusje, nr 36(1), s. 63-74. 